\title{
PENGARUH DISIPLIN KERJA TERHADAP KINERJA KARYAWAN PADA PT PERKEBUNAN NUSANTARA XI (PERSERO) PABRIK GULA “PAGOTTAN" MADIUN
}

\author{
Devi Isma Wulayanti \\ Mahasiswa Prodi Pendidikan Ekonomi IKIP PGRI Madiun
}

\begin{abstract}
This research have a purpose to study about influence of discipline work to employees performance. Discipline represent one of factor influencing employees performance. With existence of good discipline a employees will hold responsible it's work and work will be finished effectively and is efficient. Determination of sampel in this research use saturated sampel that is all employees part of Admisistrasi, Public and Monetary on Sugar Mill "PAGOTTAN” Madiun. In this case researcher only limiting to check employees part of administration, public and monetary, because of sugar mill only operating during the month of Juny until October. While research executed during the month of Februari until May. Hence, felt researcher will not be efficient and effective if checking part of production and also parts of related to production process. Pursuant to result of research obtained the level of value of rhitung 0,752 and rtabel 0,320, on the other hand the level of $\operatorname{Sig}_{\text {hitung }} 0,000$. and $\operatorname{Sig}_{\text {prob }} 0,05$. Matter this means that value of $r_{\text {count }} \geq$ $r_{\text {table }}(0,752 \geq 0,320)$ or $\operatorname{Sig}_{\text {count }} \leq \operatorname{Sig}_{\text {prob }}(0,000 \leq 0,05)$. While, level of R2 (R Square) 0,566 . Becoming, contribution influence of Discipline Work to performance equal to $56,6 \%$ while the rest equal to $43,4 \%$ influenced by other factor. From result of test of $\mathrm{F}$ obtained the level of value of $\mathrm{F}_{\text {count }} 46,973$ and $\mathrm{F}_{\text {table }} 4,113$, on the other hand the level of $\operatorname{Sig}_{\text {count }} 0,000$ and of $\operatorname{Sig}_{\text {prob }} 0,05$ matter this means that value of $F_{\text {count }} \geq F_{\text {table }}(46,973 \geq$ $4,113)$ or $\operatorname{Sig}_{\text {count }} \leq \operatorname{Sig}_{\text {prob }}(0,000 \leq 0,05)$. In test of $t$ can be made line of regresi the following $\mathrm{Y}=21,228+0,657 \mathrm{X}$, its meaning if discipline improved once will happened increase of employees performance counted $0,657 \%$, if the other factor remain to. Level of value of $\mathrm{t}_{\text {count }} 6,854$ and $\mathrm{t}_{\text {table }} 1,688$, on the other hand the level of $\operatorname{Sig}_{\text {count }} 0,000$ and $\operatorname{Sig}_{\text {prob }} 0,05$, matter this means that value of $\mathrm{t}_{\text {count }} \geq \mathrm{t}_{\text {table }}(6,854 \geq 1,688)$ or $\operatorname{Sig}_{\text {count }} \leq \operatorname{Sig}_{\text {prob }}$ $(0,000 \leq 0,05)$. On the basis of correlation test, test $F$ and test of $t$ can be concluded that there is influence Discipline Work to Performance Employees PT. Plantation Of Nusantara XI ( Persero) Sugar Mill “PAGOTTAN” Madiun.
\end{abstract}

Keyword: discipline, performance employees, human resource

\section{PENDAHULUAN}

Perkembangan ilmu ekonomi modern tidak dapat dipungkiri turut dipengaruhi oleh perkembangan kebudayaan masyarakat khususnya teknologi yang berorientasi pada industrialis. Hal ini ditandai dengan pembangunan pabrik-pabrik yang digerakan tidak lagi oleh tenaga manusia, tetapi juga oleh mesin. Dalam industri, keberadaan pabrik merupakan kunci penentu kemampuan daya saing perusahaan. Seluruh konsep, rencana dan umpan balik yang diperoleh akan ditransformasikan ke dalam pabrik. Pabrik merupakan elemen dari perusahaan yang menerjemahkan seluruh 
kebutuhan manajemen agar dapat menjawab permintaan pasar (Rika Ampuh Hadiguna, 2009:1).

Pada masa kolonial belanda terdapat pabrik-pabrik yang sukses pada masanya. Beberapa pabrik tersebut antara lain yaitu pabrik kopi, cengkeh, gula dan masih banyak lagi pabrik yang lain dan kebanyakan bahan bakunya berasal dari hasil perkebunan. Salah satu pabrik gula yang terkenal dari peninggalan kolonial belanda yaitu pabrik gula Pagottan, pabrik gula biasanya beroperasi setiap musim panen tebu yaitu antara bulan Juni sampai Oktober karena bahan utama pembuatan gula adalah tebu.

Gula merupakan salah satu komoditi bahan pokok yang banyak diperlukan banyak orang. Pabrik gula Pagotan ini memiliki keunggulan yaitu warna gulanya tidak terlalu putih, terkenal manis dan butiran kristalnya agak lebih besar dibandingkan dengan gula yang diproduksi pabrik yang modern sekarang ini. Bahan bakunya pun berasal dari tebu asli tanpa adanya campuran dari bahan lain sehingga tidak diragukan lagi rasanya. Selain itu bahan baku yang berupa tebu juga mudah didapat karena banyak petani yang menanam tebu di sekitar pabrik.

Pabrik gula Pagottan ini merupakan pabrik yang sudah berdiri sejak jaman kolonial belanda. Tetapi sampai saat ini masih beroperasi dan memberikan peluang kerja bagi masyarakat sekitar. Pabrik gula ini hanya beroperasi antara tiga sampai lima bulan dalam satu tahun sampai habisnya persediaan bahan baku atau tebu yang ada. Selain itu pabrik gula ini juga memberikan harga sesuai dengan pasaran yang relatif murah dan mampu bersaing di dunia usaha dengan kualitas yang bagus.

Dalam pengolahan suatu pabrik tersebut tentunya tidak lepas dari peran tenaga kerja. Tenaga kerja merupakan salah satu sumber daya manusia (SDM) yang sangat menentukan kemajuan suatu perusahaan ataupun pabrik. Dengan adanya sumber daya manusia yang berkualitas akan mendorong suatu perusahaan ataupun organisasi, tergantung bagai- mana perusahaan tersebut mengolah sumber daya manusia menjadi berkualitas.

Pada dasarnya, sumber daya manusia adalah suatu sumber daya yang sangat dibutuhkan oleh suatu organisasi. Sebab, sumber daya manusia adalah sumber yang berperan aktif terhadap jalannya suatu organisasi dan proses pengambilan keputusan (Edy Sutrisno, 2010:2).

Oleh Karena itu, SDM yang diperlukan pada saat ini adalah SDM yang sanggup menguasai teknologi dengan cepat, adaptif dan responsif terhadap perubahan-perubahan teknologi. Dalam kondisi tersebut integritas pribadi semakin penting untuk memenangkan persaingan. Agar perusahaan mampu terus bertahan dan bersaing, dominasi teknologi saja tidak cukup jika tidak ditunjang oleh SDM yang handal (Edy Sutrisno, 2010:1).

Untuk mendapatkan SDM yang berkualitas perlu adanya suatu penilaian kinerja suatu karyawan. Hal ini bertujuan untuk mendapatkan karyawan yang berkualitas dan bertanggung jawab, sehingga mampu mencapai suatu tujuan organisasi yang telah direncanakan sebelumnya.

Penilaian kinerja adalah proses yang dilakukan organisasi untuk mengevaluasi atau menilai keberhasilan karyawan dalam melaksanakan tugasnya. Penilaian dapat dilakukan dengan membandingkan hasil kerja yang dicapai karyawan dengan standar pekerjaan. Bila hasil kerja yang diperoleh sampai atau melebihi standar pekerjaan dapat dikatakan kinerja karyawan termasuk pada kategori baik. Demikian sebaliknya, seorang karyawan yang hasil pekerjaannya tidak mencapai standar pekerjaan termasuk pada kinerja yang tidak baik atau berkinerja rendah (Wilson Bangun, 2012:231).

Dalam mewujudkan kinerja karyawan menurut Suyadi Prawirosentono (1999:27-31), ada beberapa faktor variabel yang mempengaruhi organisasi dan kinerjanya yaitu antara lain efektivitas dan efisiensi, otoritas dan tanggung jawab, disiplin serta inisiatif. Dengan adanya faktor-faktor tersebut diharapkan perusahaan mampu mewujudkan tujuan yang telah diren- 
canakan secara efektif dan efisien.

Malayu S.P hasibuan (dalam Anwar Prabu, 2000:17-18), mengemukakan bahwa aspek-aspek yang dinilai kinerja yaitu "kesetiaan, hasil kerja, kejujuran, kedisiplinan, kreativitas, kerjasama, kepemimpinan, kepribadian, prakarsa kecakapan dan tanggung jawab”.

Salah satu faktor dan aspek yang sangat berpengaruh yaitu kedisiplinan. Dengan diterapkannya sikap disiplin pada karyawan maka akan menciptakan rasa tanggung jawab dan rasa memiliki pada perusahaan tersebut. Hal ini mendorong gairah kerja, semangat kerja dan terwujudnya tujuan perusahaan, karyawan dan masyarakat. Oleh karena itu, setiap manajer selalu berusaha agar para bawahannya mempunyai disiplin yang baik. Seorang manajer dikatakan efektif dalam kepemimpinannya jika para bawahannya berdisiplin baik.

Dalam hal ini, untuk melakukan proses itu semua memerlukan sumber daya manusia yang baik dan berkualitas. Dalam mewujudkannya tidak terlepas dari peran karyawan. Kinerja karyawan sangat diperlukan untuk menentukan keberhasilan dari tujuan sebuah organisasi atau perusahaan. Salah satu hal yang dapat mendukung terwujudnya kinerja karyawan yaitu didukung adanya disiplin karyawan yang tinggi serta didukung oleh faktor-faktor lain yang saling berkaitan. Dengan adanya disiplin dari para karyawan, maka karyawan tersebut mempunyai kinerja yang baik pula sehingga dapat mencapai tujuan perusahaan secara efektif dan efisien.

Definisi kinerja karyawan yang dikemukakan Bambang Kusriyanto (dalam Anwar Prabu Mangkunegara, 2005:9) adalah "perbandingan hasil yang dicapai dengan peran serta tenaga kerja persatuan waktu (lazimnya per jam)”.

Menurut Anwar Prabu Mangkunegara (2005:9) "kinerja karyawan (prestasi kerja) adalah hasil kerja secara kualitas dan kuantitas yang dicapai oleh seorang karyawan dalam melaksanakan tugasnya sesuai dengan tanggung jawab yang diberikan”.
Menurut Veithzal dan Ella Jauvani (2009:548-549), kinerja merupakan perilaku nyata yang ditampilkan setiap orang sebagai prestasi kerja yang dihasilkan oleh karyawannya sesuai dengan perannya dalam perusahaan.

Menurut Schwartz (dalam Wibowo, 2007:9) memandang manajemen kinerja sebagai gaya manajemen yang dasarnya adalah komunikasi terbuka antara manajer dan karyawan yang menyangkut penetapan tujuan, memberikan umpan balik baik dari manajer kepada karyawan maupun sebaliknya dari karyawan kepada manajer, demikian pada penilaian kinerja.

Dari beberapa uraian di atas dapat disimpulkan bahwa kinerja karyawan merupakan suatu hasil yang dicapai sesuai dengan tugas dan tanggung jawabnya baik secara kualitas maupun kuantitas yang dasarnya adalah komunikasi terbuka antara manajer dengan karyawannya atau sebaliknya, untuk mencapai tujuan atau rencana suatu organisasi.

Menurut Suyadi Prawirosentono (1999: 27-32), faktor-faktor variabel yang mempengaruhi organisasi dan kinerjanya antara lain: (1) Efektivitas dan Efisiensi.

Efektivitas dari kelompok (organisasi perusahaan) adalah bila tujuan kelompok tersebut dapat dicapai sesuai dengan kebutuhan yang direncanakan. Sedangkan efisiensi berkaitan dengan jumlah pengorbanan yang dikeluarkan dalam upaya mencapai tujuan. Bila pengorbanannya dianggap terlalu besar, maka dapat dikatakan tidak efisien; (2) Otoritas dan tanggung jawab (Authority and Responsibility). Wewenang adalah hak seseorang untuk memeberikan perintah (kepada bawahan), sedangkan tanggung jawab adalah bagian yang tidak terpisahkan atau segala akibat dari kepemilikan wewenang tersebut. Bila ada wewenang berarti dengan sendirinya muncul tanggung jawab. Hak atau wewenang yang diberikan kepada seseorang dalam suatu organisasi akan berkaitan dengan tanggung jawab atas wewenang yang dimiliki; (3) Disiplin (discipline). Disiplin karyawan adalah ketaatan karyawan bersangkutan dalam menghormati 
perjanjian kerja dengan peusahaan di mana dia bekerja. Disiplin meliputi ketaatan dan hormat terhadap perjanjian yang dibuat antara perusahaan dan karyawan. Disiplin juga berkaitan erat dengan sanksi yang perlu dijatuhkan kepada pihak yang melanggar. Dalam hal seorang karyawan melanggar peraturan yang berlaku dalam organisasi perusahaan, maka karyawan bersangkutan harus sanggup menerima hukuman yang berlaku; (4) Inisiatif (Initiative). Disiplin tanpa disertai oleh sikap inisiatif para peserta organisasi perusahaan, menyebabkan organisasi kekurangan energi dalam mencapai tujuan. Inisiatif seseorang (atasan atau karyawan) berkaitan dengan daya pikir, kreativitas dalam bentuk ide untuk merencanakan sesuatu yang berkaitan dengan tujuan organisasi. Setiap inisiatif sebaiknya mendapat perhatian atau tanggapan positif dari atasan, kalau memang dia atasan yang baik. Atasan yang buruk akan selalu mencegah inisiatif bawahan, lebih-lebih bawahan yang kurang disenangi. Bila atasan selalu menjegal setiap inisiatif, tanpa memberikan penghargaan berupa argumentasi yang jelas dan mendukung, menyebabkan organisasi akan kehilangan energi atau daya dorong untuk maju. Dengan perkataan lain inisiatif peserta organisasi merupakan daya dorong kemajuan yang akhirnya akan mempengaruhi kinerja organisasi bersangkutan.

Menurut Wilson Bangun (2012:231), penilaian kinerja adalah proses yang dilakukan organisasi untuk mengevaluasi atau menilai keberhasilan karyawan dalam melaksanakan tugasnya. Penilaian dapat dilakukan dengan membandingkan hasil kerja yang dicapai karyawan dengan standar pekerjaan.

Menurut Agus Sunyoto (dalam Anwar Prabu, 2005:11), bahwa kegunaan penilaian prestasi kerja (kinerja) karyawan adalah: (1) Sebagai dasar dalam pengambilan keputusan yang digunakan untuk prestasi, pemberhentian dan besarnya balas jasa; (2) Untuk mengukur sejauh mana seorang karyawan dapat menyelesaikan pekerjaannya; (3) Sebagai dasar untuk mengevaluasi efektivitas seluruh kegiatan dalam perusahaan; (4) Sebagai dasar un- tuk mengevaluasi progam latihan dan keefektifan jadwal kerja, struktur organisasi, gaya pengawasan, kondisi kerja dan pengawasan; (5) Sebagai indikator untuk menentukan kebutuhan akan latihan bagi karyawan yang berada di dalam organisasi; (6) Sebagai alat untuk meningkatkan motivasi kerja karyawan sehingga dicapai performance yang baik; (7) Sebagai alat untuk dapat melihat kekurangan atau kelemahan karyawan dan meningkatkan kemampuan karyawan selanjutnya; (8) Sebagai kriteria menentukan, seleksi dan penempatan karyawan; (9) Sebagai alat untuk memperbaiki atau mengembangkan kecakapan karyawan; (10) Sebagai dasar untuk meperbaiki atau mengembangkan uraian tugas (job description).

Dari uraian di atas dapat disimpulkan bahwa penilaian atau evaluasi kinerja merupakan suatu alat untuk memperbaiki dan meningkatkan kinerja guna mencapai tujuan suatu organisasi atau perusahaan yang efektif dan efisien.

Menurut Moehariono (2009:64), Lingkungan akuntabilitas mengacu pada kondisi dimana didalamnya harus dapat berjalan dengan baik dan sempurna, maka secara khusus, suatu lingkungan yang memiliki akuntabilitas adalah kondisi dimana di dalamnya ada individu, tim, organisasi yang merasa bahwa:

(1) Termotivasi untuk melaksanakan wewenang mereka dan memenuhi tanggung jawabnya masing-masing; (2) Mendorong mereka untuk meaksanakan pekerjaan dan mencapai hasil yang diinginkan; (3) Memberikan inspirasi untuk membagi dan melaporkan hasil pekerjaan mereka; (4) Mendorong kemauan untuk mau menerima kewajiban dan hasil kerja tersebut.

Jadi, akuntabilitas karyawan merupakan pertanggung jawaban yang diberikan karyawan kepada perusahaan atau organisasi atas tugas yang telah diberikan kepadanya.

Prinsip dasar manajemen kinerja menjadi pondasi yang kuat bagi kinerja organisasi untuk mencapai tujuan. Menurut Wibowo (2007:12-17), bahwa prinsip dasar manajemen kinerja antara lain adalah sebagai berikut: (1) 
Kejujuran. Kejujuran menampakkan diri dalam komunikasi umpan balik yang jujur di antara manajer, pekerja dan rekan kerja. Kejujuran termasuk mengekspresikan pendapat, menyampaikan fakta, memberikan pertimbangan dan perasaan; (2) Pelayanan. Setiap aspek dalam proses kinerja harus memberikan pelayanan kepada setiap stakeholder yaitu pekerja, manajer, pemilik dan pelanggan. Dalam proses manajemen kinerja, umpan balik dan pengukuran harus membantu pekerja dan perencanaan kinerja; (3) Tanggung jawab. Tanggung jawab merupakan prinsip dasar di belakang pengembangan kinerja. Dengan memahami dan menerima tanggung jawab atas apa yang mereka kerjakan dan tidak kerjakan untuk mencapai tujuan mereka, pekerja belajar tentang apa yang perlu mereka perbaiki; (4) Bermain. Manajemen kinerja menggunakan prinsip bahwa bekerja sama dengan bermain.dengan prinsip bermain, dalam manajemen kinerja orang mendapatkan kepuasan dari apa yang mereka kerjakan. Apabila tidak menerapkan prinsip bermain bekerja akan menjadi beban; (5) Rasa kasihan. Rasa kasihan merupakan prinsip bahwa manajer memahami dan empati terhadap orang lain; (6) Perumusan tujuan. Manajemen kinerja dimulai dengan melakukan perumusan dan mengklasifikasi terlebih dahulu tujuan yang hendak dicapi organisasi; (7) Konsesus dan kerja sama. Manajemen kinerja mengandalkan pada konsesus dan kerja sama antara atasan dan bawahannya daripada menekankan kontrol dan melakukan paksaan; (8) Berkelanjutan. Manajemen kinerja merupakan suatu proses yang sifatnya berlangsung secara terus menerus, berkelanjutan, bersifat evolusioner, di mana kinerja secara bertahap selalu diperbaiki sehingga menjadi semakin baik; (9) Komunikasi dua arah. Manajemen kinerja merupakan gaya manajemen yang bersifat terbuka dan jujur serta mendorong terjadinya komunikasi dua arah antara atasan dan bawahan. Komunikasi dua arah menunjukkan adanya sikap keterbukaan dan saling pengertian antara dua pihak; (10) Umpan balik. Pelaksanaan manajemen kinerja memerlukan umpan balik terus- menerus. Umpan balik memungkinkan pengalaman yang diperoleh dari pekerjaan oleh individu dipergunakan untuk memodifikasi tujuan organisasi.

Menurut Anwar Prabu Mangkunegara (2005:13), bahwa prinsip dasar evaluasi kinerja adalah sebagai berikut: (1) Fokusnya adalah membina kekuatan untuk menyelesaikan setiap persoalan yang timbul dalam pelaksanaan evaluasi kinerja. Jadi bukan semata-mata menyelesaikan persoalan itu sendiri, namun pimpinan dan karyawan mampu menyelesaikan persoalan dengan baik setiap saat, setiap ada persoalan baru. Jadi yang penting adalah kemampuannya; (2) Selalu didasarkan atas suatu pertemuan pendapat, misalnya dari hasil diskusi antara karyawan dengan atasannya langsung, suatu diskusi yang kontruktif untuk mencari jalan terbaik dalam meningkatkan mutu dan baku yang tinggi; (3) Suatu proses manajemen yang alami, jangan merasa dan menimbulkan kesan terpaksa, namun dimasukkan secara sadar ke dalam corporate planning, dilakukan secara periodik, terarah dan terprogam, bukan kegiatan yang hanya setahun sekali atau kegiatan yang dilakukan jika manajer ingat saja.

Jadi. prinsip dasar dalam kinerja yaitu untuk menjalin komunikasi dan hubungan baik antara atasan dan karyawan. Dengan adanya komunikasi maka dapat mempermudah karyawan dalam melaksanakan tugas yang diembannya. Sehingga hasil yang diperoleh dapat sesuai dengan tujuan perusahaan.

Selain itu, Menurut Siswanto Sastrohadiwiryo (2005:291), “Disiplin kerja dapat didefinisikan sebagai suatu sikap menghormati, menghargai dan taat kepada peaturanperaturan yang berlaku, baik yang tertulis maupun tidak tertulis serta sanggup menjalankannya dan tidak mengelak untuk menerima sanksi-sanksinya apabila ia melanggar tugas dan wewenang yang diberikan kepadanya”.

Menurut Veithzal Rivai (2005:444), disiplin kerja adalah suatu alat yang digunakan para manajer untuk berkomunikasi dengan karyawan agar bersedia untuk mengubah suatu 
perilaku serta sebagai suatu upaya untuk meningkatkan kesadaran dan kesediaan seseorang mentaati semua peraturan perusahaan dan norma-norma soaial yang berlaku.

Menurut Malayu S.P. Hasibuan (2000: 190), kedisiplinan adalah kesadaran dan kesediaan seseorang menaati semua peraturan perusahaan dan norma-norma sosial yang berlaku.

Menurut Singodimejdo (dalam Edy Sutrisno, 2010:86), kedisiplinan adalah sikap kesediaan dan kerelaan seseorang untuk mematuhi dan menaati norma-norma peraturan yang berlaku disekitarnya.

Dari beberapa pengertian di atas, dapat disimpulkan bahwa disiplin adalah sikap kesediaan dan kerelaan seseorang untuk menaati serta menghormati segala normanorma dan peraturan yang berlaku, baik yang tertulis maupun tidak tetulis, serta mau menerima sanksi apabila melakukan kesalahan.

Menurut Singodimejo (dalam Edy Sutrisno, 2010:89-92), bahwa faktor yang mempengaruhi disiplin pegawai adalah: (1) Besar kecilnya pemberian kompensasi. Besar kecilnya kompensasi dapat mempengaruhi tegaknya disiplin. Para karyawan akan mematuhi segala peraturan yang berlaku, bila ia mendapat jaminan balas jasa yang setimpal dengan jerih payahnya yang telah dikontribusikan bagi perusahaan; (2) Ada tidaknya keteladanan pimpinan dalam perusahaan. Keteladanan pimpinan sangat penting sekali, karena dalam lingkungan perusahaan, semua karyawan akan selalu memperhatikan bagaimana pimpinan dapat menegakkan disiplin dirinya dan bagaimana ia dapat mengendalikan dirinya dari ucapan, perbuatan dan sikap yang dapat merugikan aturan disiplin yang sudah diterapkan; (3) Ada tidaknya aturan pasti yang dapat dijadikan pegangan. Pembinaan disiplin tidak akan dapat terlaksana dalam perusahaan, bila tidak ada aturan tertulis yang pasti untuk dapat dijadikan pegangan bersama; (4) Keberanian pimpinan dalam mengambil tindakan Bila ada seorang karyawan yang melanggar disiplin, maka perlu keberanian pimpinan untuk mengambil tindakan yang sesuai dengan tingkat pelanggaran yang dibuatnya. Dengan adanya tindakan terhadap pelanggaran disiplin, sesuai dengan sanksi yang ada, maka semua karyawan akan merasa terlindungi dan dalam hatinya berjanji tidk akan berbuat hal serupa; (5) Ada tidaknya pengawasan pimpinan. Dalam setiap kegiatan yang dilakukan oleh perusahaan perlu adanya pengawasan yang akan mengarahkan para karyawan agar dapat melaksanakan pekerjaan dengan tepat dan sesuai dengan yang telah ditetapkan; (6) Ada tidaknya perhatian kepada para karyawan. Karyawan adalah manusia yang mempunyai perbedaan karakter antara yang satu dengan yang lain. Seseorang karyawan tidak hanya puas dengan penerimaan kompensasi yang tinggi, pekerjaan menantang, tetapi juga mereka masih membutuhkan perhatian yang besar dari pimpinannnya sendiri; (7) Diciptakan kebiasaan-kebiasaan yang mendukung tegaknya disiplin.

Menurut Veithzal Rivai (2005:444-445), terdapat empat perspektif daftar yang menyangkut disiplin kerja antara lain yaitu: (1) Disiplin retributif. Para pengambil keputusan mendisiplinkan dengan suatu cara yang proporsional terhadap sasaran. Dengan tidak melakukan hal seperti itu akan dianggap tidak adil oleh orang-orang yang bertindak secara tidak tepat. Tujuannya akhirnya menghukum si pelanggar; (2) Disiplin korektif. Pelanggaranpelanggaran terhadap peraturan-peraturan harus diperlakukan sebagai masalah-masalah yang dikoreksi daripada sebagai pelanggaranpelanggaran yang mesti dihukum. Hukuman akan lunak sebatas pelanggar menunjukkan kemauan untuk mengubah perilakunya. Tujuannya adalah untuk membantu karyawan mengoreksi perilaku yang tidak dapat diterima sehingga dia dapat terus dikaryakan oleh perusahaan; (3) Perspektif hak-hak individu. Disiplin hanya tepat jika terdapat alasan yang adil untuk menjatuhkan hukuman. Hak-hak karyawan lebih diutamakan dari pada tindakan disiplin; (4) Utilatirian. Memastikan bahwa faedah-faedah tindakan disiplin melebihi konsekuensi-konsekuensi negatifnya.

Menurut Siswanto sastrohadiwiryo 
(2005:291), bahwa secara khusus tujuan pembinaan disiplin kerja para tenaga kerja, antara lain : (1) Agar para tenaga kerja menepati segala peraturan dan kebijakan ketenagakerjaan maupun peraturan dan kebijakan perusahaan yang berlaku, baik tertulis maupun tidak tertulis, serta melaksanakan perintah manajemen; (2) Dapat melaksanakan pekerjaan dengan sebaik-baiknya serta mampu memberikan pelayanan yang maksimum kepada pihak tertentu yang berkepentingan dengan perusahaan sesuai dengan bidang pekerjaan yang diberikan kepadanya; (3) Dapat menggunakan dan memelihara sarana dan prasarana, barang dan jasa perusahaan dengan sebaik-baiknya; (4) Dapat bertindak dan berperilaku sesuai norma-norma yang berlaku pada perusahaan. Tenaga kerja mampu menghasilkan produktivitas yang tinggi sesuai dengan harapan perusahaan, baik dalam jangka pendek maupun jangka panjang.

Dari uraian di atas dapat disimpulkan bahwa tujuan dari pembinaan disiplin dimaksudkan agar karyawan dapat menaati dan melaksanakan peraturan yang ada serta bertindak sesuai norma-norma yang ada. Sehingga dapat melaksanakan dan menyelesaikan tugastugasnya dengan baik dan penuh rasa tanggung jawab.

Tujuan utama pengadaan sanksi disiplin kerja bagi para tenaga kerja yang melanggar norma-norma perusahaan adalah memperbaiki dan mendidik para tenaga kerja yang melakukan pelanggaran disiplin. Menurut Siswanto Sastrohadiwiryo (2005:293), pada umumnya sebagai pegangan manajer meskipun tidak mutlak, bahwa tingkat dan jenis sanksi disiplin dibagi sebagai berikut: (1) Sanksi disiplin berat. Sanksi disiplin berat misalnya: (a) Pembebasan dari jabatan/pekerjaan untuk dijadikan sebagai tenaga kerja biasa bagi yang memegang jabatan, (b) Pemutusan hubungan kerja dengan hormat atas permintaan sendiri tenaga yang bersangkutan, (c) Pemutusan hubungan kerja tidak dengan hormat sebagai tenaga kerja di perusahaan; (2) Sanksi disiplin sedang. Sanksi disiplin sedang misalnya: (a) Penundaan pem- berian kompensasi yang sebelumnya telah dirancangkan sebagaimana tenaga kerja lainnya, (b) Penurunan upah sebesar satu kali yang biasanya diberikan harian, mingguan atau bulanan, (c) Penundaan program promosi bagi tenaga kerja yang bersangkutan pada jabatan yang lebih tinggi; (3) Sanksi disiplin ringan. Sanksi disiplin ringan misalnya: (a) Teguran lisan kepada tenaga kerja yang bersangkutan, (b) Teguran tertulis, (c) Pernyataan tidak puas secara tertulis.

Dalam pemberian sanksi kepada para tenaga kerja hendaknya harus adil sesuai dengan pelanggaran yang mereka lakukan. Pemberian sanksi harus dipertimbangkan secara cermat, teliti dan saksama sebelum dijatuhkannya sanksi kepada tenaga kerja yang melanggar. Pemberian sanksi ini bertujuan agar tenaga kerja mematuhi norma atau aturan yang berlaku dalm perusahaan tersebut serta diharapkan tidak mengulangi pelanggaran yang telah mereka perbuat.

Disiplin yang baik mencerminkan besarnya rasa tanggung jawab seseorang terhadap tugas-tugas yang diberikan kepadanya. Hal ini mendorong gairah kerja, semangat kerja dan terwujudnya tujuan perusahaan, karyawan dan masyarakat. Oleh karena itu, setiap manajer selalu berusaha agar para bawahannya mempunyai disiplin yang baik. Seorang manajer dikatakan efektif dalam kepemimpinannya jika para bawahannya berdisiplin baik (Malayu S.P. Hasibuan, 2000:190).

Jadi, kedisiplinan adalah fungsi MSDM yang terpenting dan menjadi tolok ukur untuk mengukur /mengetahui apakah fungsi-fungsi MSDM lainnya secara keseluruhan telah dilaksanakan dengan baik atau tidak. Kedisiplinan karyawan yang baik, mencerminkan bahwa fungsi-fungsi MSDM lainnya telah dilaksanakan sesuai dengan rencana. Sebaliknya jika kedisiplinan karyawan kurang baik, berarti penerapan fungsi-fungsi MSDM pada perusahaan kurang baik (Malayu S.P Hasibuan, 2000:195) .

Untuk itu kedisiplinan dapat digunakan sebagai tolok ukur dalam penilaian kinerja karyawan. Dengan adanya disiplin kerja yang 
baik diharapkan mampu menciptakan kinerja (prestasi kerja) yang baik pula. Sehingga secara tidak langsung akan mempengaruhi kemajuan suatu perusahaan.

Dalam hal ini pabrik gula Pagottan juga memerlukan sumber daya manusia yang disiplin dan berkualitas dalam bidangnya. Sehingga akan mendapatkan kinerja karyawan yang diharapkan mampu bersaing di dunia global. Serta dapat berkembang dan mampu terus bertahan sampai saat sekarang di tengah persaingan yang semakin ketat dalam dunia bisnis.

\section{METODE PENELITIAN}

Penelitian ini dilaksanakan di PT. Perkebunan Nusantara XI (Persero), Pabrik Gula "PAGOTTAN" Madiun, Jl.Raya Ponorogo, Telp.(0351) 367541. Dalam penelitian ini menggunakan desain penelitian deskriptif. Menurut Husein Umar (2011:34), desain deskriptif bertujuan untuk menguraikan sifat atau karakteristik dari suatu fenomena tertentu. Jadi dalam riset dengan desain ini jangan melakukan kesimpulan yang terlalu jauh atas data yang ada, karena tujuan dari desain ini hanya mengumpulkan fakta dan menguraikannya secara menyeluruh dan teliti sesuai dengan persoalan yang akan dipecahkan.

Sehubungan dengan penelitian ini peneliti menetukan dua variabel yaitu variabel bebas (X) adalah disiplin kerja dan variabel terikat (Y) adalah kinerja karyawan.

Adapun populasi dalam penelitian ini adalah karyawan PT. Perkebunan Nusantara XI (Persero) Pabrik Gula "PAGOTTAN" Madiun bagian administrasi, keuangan dan umum yang seluruhnya berjumlah 38 orang . Adapun sampel dalam penelitian ini adalah karyawan PT. Perkebunan Nusantara XI (Persero) Pabrik Gula "PAGOTTAN” Madiun bagian administrasi, keuangan dan umum yang seluruhnya berjumlah 38 orang.

Teknik pengambilan sampling yang akan digunakan dalam penelitian ini adalah teknik sampling jenuh. Menurut Sugiyono (2009: 124), sampling jenuh adalah teknik penentu- an sampel bila semua anggota populasi digunakan sebagai sampel. Instrumen yang digunakan dalam penelitian ini adalah kuesioner yang merupakan teknik pengumpulan data melalui daftar pernyataan yang diajukan kepada responden. Sistem yang digunakan berupa pemberian skor berdasarkan skala Likert. Dimana masing-masing variabel terdiri dari 20 soal. Jadi keseluruhan soal berjumlah 40 butir.

\section{HASIL PENELITIAN}

\section{Variabel Disiplin Kerja}

Variabel disiplin kerja dapat dideskripsikan dengan jumlah data (N) sebanyak 38 orang memiliki deskripsi data sebagai berikut: (a) Jumlah skor total 2338; (b) Nilai rata-rata hitung (mean) sebesar 61.63; (c) Median sebesar 61.00; (d) Modus sebesar 59; (e) Standar Deviasi sebesar 6.908; (f) Nilai minimum sebesar 43; (g) Nilai maksimum sebesar 76.

\section{Variabel Kinerja Karyawan}

Variabel kinerja karyawan dapat dideskripsikan dengan jumlah data $(\mathrm{N})$ sebanyak 38 orang memiliki deskripsi data sebagai berikut: (a) Jumlah skor total 2342; (b) Nilai ratarata hitung (mean) sebesar 61.63; (c) Median sebesar 60.00; (d) Modus sebesar 60; (e) Standar Deviasi sebesar 6.029; (f) Nilai minimum sebesar 50; (g) Nilai maksimum sebesar 74.

\section{Hasil Uji Korelasi}

Berdasarkan uji korelasi bahwa besarnya nilai $r_{\text {hitung }}$ adalah 0,752 dan $r_{\text {tabel }} 0,320$ dilain pihak besarnya $\operatorname{Sig}_{\text {hitung }}$ 0,000 dan Sig ${ }_{\text {prob }}$ 0,05. Hal ini berarti bahwa nilai $r_{\text {hitung }} \geq r_{\text {tabel }}(0,752$ $\geq 0,320)$ atau $\operatorname{Sig}_{\text {hitung }} \leq \operatorname{Sig}_{\text {prob }}\left(0,000 d^{\prime \prime} 0,05\right)$. Atas dasar korelasi tersebut dapat disimpulkan Ho ditolak, artinya ada hubungan antara Disiplin Kerja dan Kinerja Karyawan pada PT. Perkebunan Nusantara XI (Persero) Pabrik Gula "PAGOTTAN" Madiun. 
Dalam Uji determinasi yang diperoleh nilai $\mathrm{R}^{2}$ ( $\mathrm{R}$ Square) atau koefisien determinasi yang digunakan untuk mengetahui prosentase sumbangan disiplin kerja terhadap kinerja karyawan. Berdasarkan tabel 4.9 di atas dapat diketahui besarnya $\mathrm{R}^{2}$ (R Square) adalah 0,566. Jadi, sumbangan pengaruh Disiplin Kerja terhadap kinerja sebesar 56,6\%, sedangkan sisanya sebesar $43,4 \%$ dipengaruhi oleh faktor lain.

\section{Hasil Uji F/ Fisher}

Berdasarkan uji F diketahui bahwa besarnya nilai $\mathrm{F}_{\text {hitung }}$ adalah 46,973 dan $\mathrm{F}_{\text {tabel }} 4,113$, dilain pihak besarnya Sig $_{\text {hitung }}$ 0,000 dan Sig ${ }_{\text {prob }}$ ' 0,05 hal ini berarti bahwa nilai $\mathrm{F}_{\text {hitung }} \geq \mathrm{F}_{\text {tabel }}$ $(46,973 \geq 4,113)$ atau $\operatorname{Sig}_{\text {hitung }} \leq \operatorname{Sig}_{\text {prob }}(0,000$ $\leq 0,05)$. Atas dasar Uji Fisher tersebut dapat disimpulkan Ho ditolak, artinya ada pengaruh antara Disiplin Kerja terhadap Kinerja Karyawan pada PT. Perkebunan Nusantara XI (Persero) Pabrik Gula “PAGOTTAN” Madiun.

Dalam Uji Fisher selain dapat digunakan untuk mencari pengaruh, dapat juga digunakan untuk menguji linearitas. Karena $\mathrm{F}_{\text {hitung }}$ adalah 46,973 $\geq \mathrm{F}_{\text {tabel }} 4,113$, berarti ada hubungan yang linear antara disiplin kerja dan kinerja karyawan

\section{Uji t}

Atas dasar uji t dapat dibuat garis regresi sebagai berikut $\mathrm{Y}=21,228+0,657 \mathrm{X}$, artinya apabila disiplin kerja ditingkatkan satu kali akan terjadi kenaikan kinerja karyawan sebanyak 0,657\%, apabila faktor yang lainnya tetap.

Berdasarkan tabel 4.11 di atas diketahui bahwa besarnya nilai $t_{\text {hitung }}$ adalah 6,854 dan $\mathrm{t}_{\text {tabel }} 1,688$ dilain pihak besarnya Sig $_{\text {hitung }} 0,000$ dan Sig $_{\text {prob }}$ 0,05, hal ini berarti bahwa nilai $t_{\text {hitung }}$ $\geq \mathrm{t}_{\text {tabel }}(6,854 \geq 1,688)$ atau $\operatorname{Sig}_{\text {hitung }} \leq \operatorname{Sig}_{\text {prob }}$ $(0,000 \leq 0,05)$. Atas dasar uji beda pengaruh tersebut dapat disimpulkan Ho ditolak, artinya ada beda pengaruh antara Disiplin Kerja terhadap Kinerja Karyawan pada PT. Perkebunan Nusantara XI (Persero) Pabrik Gula “PAGOTTAN” Madiun.

\section{Simpulan Hasil Analisis}

Berdasarkan analisis data yang telah di dapatkan maka dapat dibuat kesimpulan sebagai berikut.

\section{Simpulan Uji Korelasi}

Hasil dari pengujian korelasi dapat diperoleh besarnya nilai $r_{\text {hitung }}$ adalah 0,752 dan $r_{\text {tabel }}$ 0,320 , dilain pihak besarnya $r_{\text {hitung }} \geq r_{\text {tabel }}(0,752$ $\geq 0,320)$ atau $\operatorname{Sig}_{\text {hitung }} \leq \operatorname{Sig}_{\text {prob }}(0,000 \leq 0,05)$.

Selain itu diperoleh nilai $\mathrm{R}^{2}$ adalah 0,566 jadi sumbangan pengaruh disiplin kerja terhadap kinerja karyawan yaitu 56,6\%, dan 43,4\% dipengaruhi oleh faktor lain. Atas dasar korelasi tersebut dapat disimpulkan tolak Ho, artinya ada hubungan antara Disiplin Kerja dan Kinerja Karyawan pada PT. Perkebunan Nusantara XI (Persero) Pabrik Gula “PAGOTTAN” Madiun.

\section{Simpulan Uji Fisher}

Hasil pengujian Fisher dengan uji Anova dapat diperoleh besarnya nilai $\mathrm{F}_{\text {hitung }}$ adalah 46,973 dan $\mathrm{F}_{\text {tabel }}$ 4,113 dilain pihak besarnya Sig $_{\text {hitung }}$ 0,000 dan Sig ${ }_{\text {prob }}$ 0,05 hal ini berarti bahwa nilai $\mathrm{F}_{\text {hitung }} \geq \mathrm{F}_{\text {tabel }}(46,973 \geq 4,113)$ atau Sig $_{\text {hitung }} \leq \operatorname{Sig}_{\text {prob }}(0,000 \leq 0,05)$. Sesuai hipotesis yang diajukan dapat disimpulkan bahwa ada pengaruh antara Disiplin Kerja terhadap Kinerja Karyawan pada PT. Perkebunan Nusantara XI (Persero) Pabrik Gula "PAGOTTAN” Madiun.

\section{Simpulan Uji t}

Dari hasil perhitungan atau pengujian yang dilakukan dapat diperoleh persamaan garis regresi sebagai berikut $\mathrm{Y}=21,228+$ 0,657X, artinya apabila disiplin kerja ditingkatkan satu kali akan terjadi kenaikan kinerja karyawan sebanyak 0,657\%, apabila faktor yang lainnya tetap.

Berdasarkan hasil uji t diperoleh besarnya nilai $\mathrm{t}_{\text {hitung }}$ adalah 6,854 dan $\mathrm{t}_{\text {tabel }} 1,688$ dilain pihak besarnya Sig ${ }_{\text {hitung }}$ 0,000 dan Sig ${ }_{\text {prob }}$ 0,05 hal ini berarti bahwa nilai $\mathrm{t}_{\text {hitung }} \geq \mathrm{t}_{\text {tabel }}(6,854 \geq$ 1,688) atau $\operatorname{Sig}_{\text {hitung }} \leq \operatorname{Sig}_{\text {prob }}(0,000 \leq 0,05)$. 
Sesuai hipotesis yang diajukan dapat disimpulkan ada beda pengaruh antara Disiplin Kerja terhadap Kinerja Karyawan pada PT. Perkebunan Nusantara XI (Persero) Pabrik Gula "PAGOTTAN” Madiun.

\section{PEMBAHASAN}

Hasil penelitian menunjukkan bahwa disiplin kerja berpengaruh terhadap kinerja karyawan. Hal ini menunjukkan bahwa disiplin kerja diperlukan oleh karyawan untuk melaksanakan tugas dan tanggung jawabnya secara efektif dan efisien, sehingga dapat meningkatkan kinerja karyawan.

\section{Pembahasan Uji Korelasi}

Untuk uji korelasi diperoleh besarnya nilai $r_{\text {hitung }}$ adalah 0,752 dan $r_{\text {tabel }} 0,320$, dilain pihak besarnya $r_{\text {hitung }} \geq r_{\text {tabel }}(0,752 \geq 0,320)$ atau $\operatorname{Sig}_{\text {hitung }} \leq \operatorname{Sig}_{\text {prob }}(0,000 \leq 0,05)$. Dengan demikian Ho ditolak, artinya ada hubungan yang signifikan antara Disiplin kerja dan kinerja karyawan pada PT.Perkebunan Nusantara XI (Persero) Pabrik Gula “PAGOTTAN” Madiun.

Selain itu diperoleh nilai $\mathrm{R}^{2}$ adalah 0,566 Menunjukkan bahwa disiplin kerja mempengaruhi kinerja karyawan sebanyak 56,6\%, sedangkan 43,4\% dipengaruhi oleh faktor lain.

\section{Pembahasan Uji Fisher}

Berdasarkan Uji Fisher diperoleh nilai $\mathrm{F}_{\text {hitung }}$ adalah 46,973 dan $\mathrm{F}_{\text {tabel }}$ 4,113 dilain pihak besarnya Sig hitung $_{0,000}$ dan Sig $_{\text {prob }}$ 0,05 hal ini berarti bahwa nilai $\mathrm{F}_{\text {hitung }} \geq \mathrm{F}_{\text {tabel }}(46,973 \geq$ $4,113)$ atau $\operatorname{Sig}_{\text {hitung }} \leq \operatorname{Sig}_{\text {prob }}(0,000 \leq 0,05)$. Atas dasar Uji Fisher tersebut dapat disimpulkan Ho ditolak, artinya ada pengaruh antara Disiplin Kerja terhadap Kinerja Karyawan pada PT. Perkebunan Nusantara XI (Persero) Pabrik Gula "PAGOTTAN” Madiun.

\section{Pembahasan Uji t}

Dapat dilihat hasil persamaan garis regresi $\mathrm{Y}=21,228+0,657 \mathrm{X}$, artinya apabila disiplin kerja ditingkatkan satu kali akan terjadi kenaikan kinerja karyawan sebanyak
0,657\%, apabila faktor yang lainnya tetap.

Berdasarkan Uji t nilai $t_{\text {hitung }}$ adalah 6,854 dan $\mathrm{t}_{\text {tabel }} 1,688$ dilain pihak besarnya Sig $_{\text {hitung }}$ 0,000 dan Sig ${ }_{\text {prob }}$ 0,05 hal ini berarti bahwa nilai $t_{\text {hitung }} \geq t_{\text {tabel }}(6,854 \geq, 688)$ atau $\operatorname{Sig}_{\text {hitung }} \leq$ $\operatorname{Sig}_{\text {prob }}(0,000 \leq 0,05)$. Atas dasar korelasi tersebut dapat disimpulkan Ho ditolak, artinya ada beda pengaruh antara Disiplin Kerja terhadap Kinerja Karyawan pada PT. Perkebunan Nusantara XI (Persero) Pabrik Gula "PAGOTTAN" Madiun.

\section{PENUTUP}

\section{Simpulan}

Berdasarkan hasil analisis data dan pembahasan pada bab sebelumnya dapat disimpulkan sebagai berikut:

Disiplin kerja yang dilaksanakan di Pabrik Gula Pagottan cukup efektif dan efisien. Hal ini dapat dilihat dari tingkat kedisiplinan yang cukup tinggi. Berdasarkan hasil penelitian yang telah dilakukan disiplin kerja memberikan pengaruh lebih dari 50\% terhadap kinerja karyawan di Pabrik Gula Pagottan Madiun. Hal ini dapat dibuktikan dari hasil analisis penelitian. Hasilnya diperoleh nilai $\mathrm{R}^{2}$ (R Square) atau koefisien determinasi sebesar 0,566 . Yang artinya disiplin kerja mempunyai sumbangan pengaruh sebesar $56,6 \%$ terhadap kinerja karyawan. Sedangkan 43,4\% dipengaruhi oleh faktor lain.

Kinerja karyawan merupakan suatu hasil kerja baik secara kualitas maupun kuantitas dalam suatu organisasi atau perusahaan. Kinerja karyawan dipengaruhi oleh beberapa faktor salah satunya yaitu disiplin kerja. Dengan diterapkannya sikap disiplin yang baik, kinerja karyawan juga berjalan dengan baik dan memperoleh hasil yang maksimal sesuai dengan rencara atau tujuan awal dari perusahaan.

Disiplin Kerja mempunyai pengaruh terhadap kinerja karyawan pada Pabrik Gula Pagottan Madiun. Terbukti dari hasil analisis regresi yang memuat uji korelasi, uji F dan uji t. Dari hasil korelasi diperoleh hasil nilai $r_{\text {hitung }}$ $\geq r_{\text {tabel }}(0,752 \geq 0,320)$ atau $\operatorname{Sig}_{\text {hitung }} \leq \operatorname{Sig}_{\text {prob }}$ 
$(0,000 \leq 0,05)$. Sedangkan nilai determinasi yang diperoleh nilai $\mathrm{R}^{2}$ ( $\mathrm{R}$ Square) adalah 0,566 . Jadi, sumbangan pengaruh Disiplin Kerja terhadap kinerja sebesar 56,6\% sedangkan sisanya sebesar 43,4\% dipengaruhi oleh faktor lain. Dari Hasil Uji F nilai $F_{\text {hitung }} \geq F_{\text {tabel }}$ $(46,973 \geq 4,113)$ atau $\operatorname{Sig}_{\text {hitung }} \leq \operatorname{Sig}_{\text {prob }}(0,000$ $\leq 0,05)$. Dari Uji t diperoleh garis regresi yaitu $\mathrm{Y}=21,228+0,657 \mathrm{X}$, artinya apabila disiplin kerja ditingkatkan satu kali akan terjadi kenaikan kinerja karyawan sebanyak 0,657\%, apabila faktor yang lainnya tetap. Sedangkan, nilai $\mathrm{t}_{\text {hitung }} \geq \mathrm{t}_{\text {tabel }}(6,854 \geq 1,688)$ atau Sig hitung $\leq$ Sig $_{\text {prob }}(0,000 \leq 0,05)$. Jadi, berdasarkan uji korelasi, uji F dan uji t dapat disimpulkan ada pengaruh Disiplin Kerja terhadap Kinerja Karyawan pada PT. Perkebunan Nusantara XI (Persero) Pabrik Gula “PAGOTTAN” Madiun.

\section{Saran}

\section{Bagi Karyawan}

Sesuai dengan hasil penelitian yang telah dilakukan. Terbukti bahwa disiplin memberikan pengaruh terhadap kinerja karyawan, maka karyawan diharapkan mampu meningkatkan kedisiplinannya dalam bekerja. Sehingga dapat mencapai tujuan perusahaan dan bertanggung jawab terhadap tugas yang telah diberikan.

\section{Bagi Pabrik Gula "PAGOTTAN" Madiun}

Berdasarkan penelitian yang telah di lakukan di Pabrik Gula Pagottan. Bahwa disiplin mempunyai pengaruh yang cukup besar, diharapkan dalam mengelola pabrik lebih meningkatkan lagi kedisiplinan. Peningkatan disiplin bisa melalui pemberian sanksi yang tegas, pemberian motivasi, pemberian hadiah maupun dengan cara yang lainnya. Seorang atasan juga harus bijak dalam menyikapi suatu sanksi ataupun pelanggaran yang telah dilakukan oleh seorang karyawan. Dengan begitu diharapkan tercipta kerjasama dan kedisiplinan yang baik.

\section{Bagi Peneliti}

Peneliti diharapkan mampu mengembangkan penelitian yang telah ada, serta mencari faktor-faktor lain yang mempunyai pengaruh bagi kinerja karyawan. Sehingga dengan adanya pengembangan penelitian dapat mengetahui cara peningkatan kinerja, baik secara kualitas maupun kuantitas dalam perusahaan ataupun organisasi.

\section{DAFTAR PUSTAKA}

Anwar Prabu Mangkunegara. 2005. Evaluasi Kinerja SDM. Bandung: Refika Aditama.

Duwi Priyatno. 2010. Teknik Mudah dan Cepat Melakukan Analisis Data Penelitian dengan SPSS dan Tanya Jawab Ujian Pendadaran. Yogyakarta: Gaya Media.

Edy Sutrisno.2010. Manajemen Sumber Daya Manusia. Jakarta: Kencana.

Husein Umar. 2000. Riset Pemasaran dan Perilaku Konsumen. Jakarta: Gramedia Pustaka Utama.

Husein Umar. 2011. Metode Penelitian untuk Skripsi dan Tesis Bisnis. Jakarta: Raja Grafindo Persada.

Juliansyah Noor. 2011. Metodologi Penelitian. Jakarta: Kencana.

Malayu S.P. Hasibuan. 2000. Manajemen Sumber Daya Manusia. Jakarta: Bumi Aksara.

Moehar Daniel. 2003. Metode Penelitian Sosial Ekonomi. Jakarta: Bumi Aksara.

Moeheriono. 2009. Pengukuran Kinerja Berbasis Kompetensi. Jakarta: Ghalia Indonesia.

Muchdarsyah. Sinungan. 2005. Produktivitas Apa dan Bagaimana. Jakarta: Bumi Aksara.

Rika Ampuh Hadiguna. 2009. Manajemen Pabrik Pendekatan Sistem untuk Efisiensi dan Efektivitas. Jakarta: Bumi Aksara.

Siswanto Sastrohadiwiryo. 2005. Manajemen Tenaga Kerja Indonesia Pendekatan Administrasi dan Operasional. Jakarta: Bumi Aksara.

Sugiyono. 2009. Metode Penelitian Pendidikan (Pendekatan Kuantitatif, Kualitatif dan $R \& D)$. Bandung: ALfabeta.

Suharsimi Arikunto. 2010. Prosedur Penelitian Suatu Pendekatan Praktik. Jakarta:Rineka Cipta. 
Sukardi. 2003. Metodologi Penelitian Pendidikan Kompetensi dan Praktiknya. Jakarta: Bumi Aksara.

Suyadi Prawirosentono. 1999. Manajemen Sumberdaya Manusia Kebijakan Kinerja Karyawan. Yogyakarta: BPFE.

Veithzal Rivai. 2005. Manajemen Sumber Daya Manusia untuk Perusahaan. Jakarta: Raja Grafindo Persada.
Veithzal Rivai dan Ella Jauvani Sagala. 2009. Manajemen Sumber Daya Manusia untuk Perusahaan. Jakarta: Raja Grafindo Persada. Wibowo. 2007. Manajemen Kinerja. Jakarta: Raja Grafindo Persada.

Wilson Bangun. 2012. Manajemen Sumber Daya Manusia. Jakarta: Erlangga. 